\title{
ANALISIS SISTEM PENILAIAN KINERJA KARYAWAN \\ DENGAN MENGGUNAKAN METODE 360 DERAJAT \\ (Studi Kasus Pada PT. Arga Bangun Bangsa)
}

\author{
Oleh : Rahmayanti, SE. MM.
}

Dosen Prodi D-III Sekretari/Adm. Perkantoran Universitas Pamulang

Rachmayanti165@gmail.com

\begin{abstract}
Abstrak
Metode penilaian kinerja 360 derajat didefinisikan sebagai metode penilaian kinerja yang dilakukan oleh banyak pihak untuk memperoleh hasil yang lebih jujur, adil, dan tepat sasaran. Sistem penilaian kinerja metode 360 derajat yang dilakukan di PT. Arga Bangun Bangsa bertujuan untuk mengetahui pelaksaan sistem penilaian kinerja menggunakan metode 360 Derajat, mengetahui variabel-variabel apa saja yang digunakan dalam penilaian kinerja tersebut, dan memperoleh optimalisasi kinerja. Metode penelitian yang digunakan dalam penelitian ini menggunakan metode kualitatif dengan pendekatan kuantitatif. Hasil penelitian yang dilakukan menunjukan bahwa PT. Arga Bangun Bangsa telah melaksanakan penilaian kinerja metode 360 derajat dalam waktu yang singkat dan berhasil menentukan karyawan terbaik dari masing-masing direktorat berdasarkan pada perhitungan variabel dan sub variabel yang digunakan. Berdasarkan pada perhitungan penilaian variabel dan sub variabel tersebut, diperoleh hasil optimalisasi penilaian kinerja dengan persentase yaitu IT dan Operational Directorate (84.92\%), Human Capital Directorate (83.88\%), Sales Directorate (83.36\%), Training Directorate (82.00\%), Finance dan Accounting Directorate (81.10\%), Corporate Secretary (78.97\%), dan Multimedia Creative Directorate (74.92\%). Sehingga dapat disimpulkan bahwa penilaian kinerja 360 derajat yang dilakukan dapat membantu perusahaan secara tepat untuk memberikan reward bagi direktorat dengan persentase tertinggi dan memberikan punishment bagi direktorat dengan persentase terendah. Perhitungan variabel dan sub variabel tersebut sekaligus membantu perusahaan untuk menemukan solusi yang tepat dalam upaya meningkatkan kualitas kinerja karyawannya.
\end{abstract}

Kata kunci: Kinerja karyawan, Penilaian Kinerja, metode penilaian kinerja 360 derajat

\section{PENDAHULUAN}

\section{Latar Belakang Masalah}

Pembinaan dan pengembangan karyawan baru ataupun lama dalam perusahaan adalah salah satu kegiatan dalam rangka penyesuaian diri dengan perubahan dan perkembangan karyawan. Karena itu perlu dilakukan penilaian atas pekerjaan yang telah dilaksanakan oleh karyawan atau disebut dengan penilaian kinerja. Penilaian kinerja menitikberatkan pada 
penelitian sebagai suatu proses pengukuran penilaian. Salah satu bentuk pendekatan dalam penilaian kinerja yaitu penilaian kinerja 360 derajat (Cumming \& Worley, 2005).

Penilaian kinerja 360 derajat yaitu instrumen yang digunakan untuk mengukur perilaku kerja karyawan berdasarkan evaluasi dari dua arah atau lebih sumber, seperti manajer (atasan), rekan kerja atau bawahan (Beehr dkk, 2001) bahkan terkadang melibatkan pihak luar atau pelanggan (Bernadin \& Russel, 1998, Kreitner \& Kinicki, 2001).

Penilaian kinerja pada dasarnya merupakan proses yang digunakan perusahaan untuk mengevaluasi job performance. Jika dikerjakan dengan benar, hal ini akan memberikan manfaat yang penting bagi karyawan, supervisor, departemen SDM, maupun perusahaan.

Supervisor dan manajer harus mengevaluasi kinerja untuk mengetahui tindakan apa yang akan diambil. Umpan balik yang spesifik memungkinkan mereka untuk membuat perencanaan karir (career planning), pelatihan dan pengembangan (training and development), peningkatan gaji (pay increase), promosi, dan keputusan-keputusan penempatan lainnya.

Penilaian kinerja berkaitan dengan kinerja dan pertanggungjawaban karyawan pada perusahaan. Dalam dunia yang bersaing secara global, perusahaan membutuhkan feed back terhadap kinerjanya sebagai pembimbing sikap untuk masa yang akan datang. Departemen SDM menggunakan informasi yang dikumpulkan melalui penilaian kinerja untuk mengevaluasi keberhasilan dari perekrutan, seleksi, orientasi, penempatan, pelatihan, dan kegiatan-kegiatan lainnya. Meskipun penilaian harian yang terus-menerus dan informal penting dilakukan untuk memperlancar operasional, penilaian formal dibutuhkan untuk membantu manajer dalam hal yang berkaitan dengan keputusan-keputusan SDM, seperti penempatan, penggajian, dan lainlain. Pada perusahaan yang ditata dengan baik, penilaian dihubungkan dengan permasalahan. Penyelia dan manajer sering menganggap penilaian formal sebagai suatu yang tidak dibutuhkan. Mereka merasa bahwa mereka telah mengetahui bagaimana pekerjaan karyawan mereka, dan mereka menganggap tidak perlu menghabiskan waktu yang berharga untuk melakukannya. Di samping itu, rancangan sistem penilaian yang kurang tepat memungkinkan terjadinya tindakan yang tidak diinginkan oleh karyawan dan supervisor.

PT. Arga Bangun Bangsa merupakan perusahaan yang bergerak di bidang konsultan SDM. Dalam perjalanannya, PT. Arga Bangun Bangsa telah menerapkan sistem penilaian kinerja dengan tujuan untuk memperoleh karyawan-karyawan yang berprestasi dan perusahaan dapat memberikan feedback positif bagi karyawan-karyawan berprestasi tersebut. Selama ini penilaian yang digunakan adalah penilaian secara psikologis dan penilaian yang menggunakan metode assessment. Sedangkan penilaian kinerja dengan metode 360 Derajat belum pernah 
digunakan pada perusahaan tersebut. Metode 360 derajat diharapkan dapat memberikan hasil penilaian yang objektif sehingga tujuan dari penilaian tersebut dapat menjadi metode yang efektif dan bermanfaat baik bagi karyawan maupun perusahaan.

\section{Identifikasi Masalah}

Berdasarkan Latar Belakang Masalah yang diuraikan diatas maka Identifikasi Masalah dalam penulisan ini adalah :

1. Sistem Penilaian Kinerja Karyawan Dengan Menggunakan Metode 360 Derajat pada PT. Arga Bangun Bangsa.

2. Penilaian kinerja berkaitan dengan kinerja dan pertanggungjawaban karyawan pada perusahaan.

\section{Perumusan Masalah}

Berdasarkan Identifikasi Masalah tersebut diatas maka Perumusan Masalah yang akan dibahas dalam penulisan ini adalah :

1. Bagaimana Sistem Penilaian Kinerja Karyawan Dengan Menggunakan Metode 360 Derajat pada PT. Arga Bangun Bangsa?

2. Apakah Penilaian kinerja berkaitan dengan kinerja dan pertanggungjawaban karyawan pada perusahaan?

\section{Metode Penelitian}

Metode penelitian yang digunakan yaitu metode kualitatif dengan pendekatan kuantitatif. Populasi yang digunakan yaitu karyawan PT. Arga Bangun Bangsa sejumlah 136 orang dengan rentan waktu penelitian yang dilakukan di PT. Arga Bangun Bangsa yaitu periode Januari 2016 hingga September 2016, dengan menggunakan teknik pengumpulan sampel proporsional random sampling, memperoleh responden sejumlah 101 orang.

\section{Populasi dan Sampel}

Populasi yang digunakan dalam penelitian ini adalah karyawan PT. Arga Bangun Bangsa yang berjumlah 136 orang, populasi ini digunakan untuk mengumpulkan data dan informasi dalam pelaksanaan penilaian kinerja karyawan dengan mengunakan metode 360 Derajat di lingkungan internal perusahaan, seperti pada tabel berikut: 
Tabel 1. Populasi Penelitian

\begin{tabular}{clc}
\hline No & \multicolumn{1}{c}{ Nama Direktorat } & Jumlah karyawan \\
\hline 1 & IT dan Operational & 15 \\
2 & Human Capital & 4 \\
3 & Sales dan Marketing & 54 \\
4 & Training & 39 \\
5 & Finance dan Accounting & 11 \\
6 & Corporate Secretary & 5 \\
7 & Multimedia Creative & 8 \\
\hline & Total & 136 \\
\hline
\end{tabular}

Teknik pengumpulan sampel dalam penelitian ini adalah proporsional random sampling yaitu pemilihan sampel secara acak sederhana secara proporsional dengan cara diundi sari populasi. Banyaknya sampel yang dihitung dengan menggunakan Rumus Slovin. Rumus Slovin digunakan untuk menentukan ukuran sampel dari populasi yang telah diketahui jumlahnya yaitu sebanyak 136 orang karyawan. Dengan batas kesalahan yang digunakan yaitu $5 \%$ berdasarkan pada ilmu-ilmu sosial yang disepakati.

Keterangan:

$$
\text { Rumus Slovin : } \mathrm{n}=\frac{\mathrm{N}}{1+\mathrm{Ne}^{2}}
$$

$\mathrm{n}=$ Ukuran Sampel

$\mathrm{N}=$ Ukuran Populasi

e = Kelonggaran ketidaktelitian karena kesalahan pengambilan sampel yang dapat ditolerir, kemudian dikuadratkan.

Berdasarkan rumus Slovin tersebut, maka besarnya penarikan jumlah sampel penelitian yaitu:

$$
\mathrm{n}=\frac{\mathrm{N}}{1+\mathrm{Ne}^{2}}=\frac{136}{1+136(0,05)^{2}}=101 \text { orang karyawan }
$$

Untuk populasi sebanyak 136 karyawan maka diperoleh jumlah sampel sebanyak 101 orang, seperti pada tabel berikut:

Tabel 2. Sampel Penelitian

\begin{tabular}{llcl}
\hline No & \multicolumn{1}{c}{ Direktorat } & Perhitungan & \multicolumn{1}{c}{ Sampel } \\
\hline 1 & IT dan Operational & $15 / 136 \times 101=11.12$ & 11 \\
2 & Human Capital & $4 / 136 \times 101=2.97$ & 3 \\
3 & Sales dan Marketing & $54 / 136 \times 101=40.10$ & 40 \\
4 & Training & $39 / 136 \times 101=28.96$ & 29 \\
5 & Finance dan Accounting & $11 / 136 \times 101=8.17$ & 8 \\
6 & Corporate Secretary & $5 / 136 \times 101=3.71$ & 4 \\
7 & Multimedia Creative & $8 / 136 \times 101=5.94$ & 6 \\
& & & Total \\
\hline
\end{tabular}




\section{PEMBAHASAN DAN HASIL}

\section{Analisis sistem penilaian kinerja menggunakan metode 360 Derajat di PT. Arga Bangun Bangsa.}

Proses penilaian kinerja dengan menggunakan metode 360 derajat yang dilakukan di PT Arga Bangun Bangsa umumnya sama dengan tabel proses penilaian kinerja yang telah dijelaskan menurut Antonioni (1996), berikut penjelasan mengenai proses penilaian kinerja menggunakan metode 360 derajat berdasarkan pada tabel di atas yaitu:

1. Input

Input meliputi praktik-praktik atau aktivitas yang biasa dilakukan sebelum penilai melakukan tugasnya dan orang yang dinilai melakukan umpan balik. Tujuan dari penerapan konsep 360 derajat untuk membantu individu agar melakukan perbaikan dan perubahan yang positif sedangkan instrumen penilaian berfungsi sebagai karangka referensi mengenai perilaku kerja yang diinginkan.

\section{Process}

Pekerjaan penilai sebenarnya dimulai ketika mereka yang dinilai menerima hasil penilaian. Pada tahap ini mereka bertanggung jawab untuk bekerja dengan umpan balik yang mereka terima dari para penyelia dan para profesional sumber daya manusia yang juga bertanggung jawab untuk membantu mereka dalam membuat manfaat yang lebih baik dari umpan balik penilaian.

\section{Outcomes}

Outcomes merupakan laporan yang diperoleh dari proses penilaian 360 derajat. Proses penilaian 360 derajat menghasilkan kesadaran individu tentang harapan penilaian yang besar terhadap dirinya. Dengan kesadaran diri dan tanggung jawab yang besar untuk merespon hasil penilaian akan menghasilkan perbaikan pada kinerja.

Dalan penelitian penilaian kinerja 360 derajat yang dilakukan di PT. Arga Bangun Bangsa menggunakan 3 (tiga) variabel yang sudah disepakati dalam meeting manajemen yang dihadiri direksi perwakilan seluruh direktorat. Variabel-variabel tersebut yaitu:

1. Kedisiplinan

Sub variabel kedisiplinan yang digunakan dalam penilaian kinerja metode 360 derajat di PT. Arga Bangun Bangsa, yaitu terbagi menjadi:

a. Kehadiran pegawai 

b. Ketetapan Waktu
c. Sanksi

2. Pekerjaan

Sub variabel Pekerjaan yang digunakan dalam penilaian kinerja metode 360 derajat di PT. Arga Bangun Bangsa, yaitu terbagi menjadi:
a. Tidak adanya kesalahan dalam menyelesaikan pekerjaan
b. Kemampuan menyelesaikan tugas sesuai target dan tepat waktu
c. Pekerjaan sesuai SOP

\section{Kemampuan Pribadi}

Sub variabel kemampuan pribadi yang digunakan dalam penilaian kinerja metode 360 derajat di PT. Arga Bangun Bangsa, yaitu terbagi menjadi:
a. Kemampuan menyelesaikan masalah
b. Kemampuan beradaptasi dengan kelompok kerja
c. Kemampuan memimpin dalam tim

Dalam mengembangkan penilaian kinerja 360 derajat umumnya suatu perusahaan menghadapi masalah karena kegagalan dalam penerapan sistem ini. Keterbatasan penilaian kinerja 360 derajat menyebabkan proses penilaian sederhana, bersifat subjektif (Longeenecker, Giola dan Sims: 1987). Dari penjelasan teori tersebut, untuk mengatasi tingkat subjektif yang terjadi dalam pengelolaan penilaian kinerja 360 derajat diperlukan keterlibatan beberapa pihak seperti: atasan, bawahan, rekan sekerja, dan karyawan yang bersangkutan. Keterlibatan ini memberikan hasil yang efektif, tidak bias dan memotivasi peningkatan kinerja. Menurut Putri (2008), manfaat yang akan diperoleh apabila organisasi di Indonesia menerapkan sistem penilaian 360 derajat adalah semua penilaian yang diberikan oleh pimpinan, bawahan, rekan sejawat dan diri sendiri dapat memberikan hasil yang sangat akurat dan obyektif mengenai kinerja pihak yang dinilai.

Namun pelaksanaan penilaian kinerja metode 360 derajat di PT. Arga Bangun Bangsa melihat dari situasi dan kondisi yang ada di perusahaan, penilai yang terlibat hanya 3 (tiga) pihak yaitu pimpinan, rekan kerja, dan bawahan, manajemen PT. Arga Bangun Bangsa dalam meeting direksi sepakat untuk tidak melibatkan diri sendiri sebagai penilai agar tidak terjadi subjektivitas yang tinggi, dikarenakan diri sendiri kemungkinan besar akan membela diri dengan memberikan nilai tertinggi berdasarkan pada rasa ingin memperoleh nilai tinggi dalam penilaian tersebut. Penjelasan mengenai pelaksanaan penilaian kinerja menggunakan metode 
360 derajat yang dilakukan di PT. Arga Bangun Bangsa, memberikan banyak informasi yang bermanfaat dan mendukung dalam pencapaian tujuan perusahaan.

\section{Analisis variabel-variabel yang digunakan dalam penilaian kinerja karyawan dengan metode 360 Derajat di PT. Arga Bangun Bangsa}

Penilaian kinerja metode 360 derajat di PT. Arga Bangun Bangsa menggunakan 3 (tiga) variabel sebagai berikut:

1. Variabel Kedisiplinan, terdiri dari sub variabel yaitu: Kehadiran Pegawai, Ketepatan Waktu, dan Sanksi.

2. Variabel Pekerjaan, terdiri dari sub variabel yaitu: Tidak adanya kesalahan dalam menyelesaikan pekerjaan, Kemampuan menyelesaikan tugas sesuai target dan tepat waktu, dan Pekerjaan sesuai SOP

3. Variabel Kemampuan Pribadi, terdiri dari sub variabel yaitu: Kemampuan menyelesaikan masalah, Kemampuan beradaptasi dengan kelompok kerja, dan Kemampuan memimpin dalam tim.

Bobot Penilaian Kinerja dengan menggunakan metode 360 derajat yang dilakukan di PT. Arga Bangun Bangsa adalah sebagai berikut:

1. Bobot Kriteria, digunakan untuk menghitung persentase antara kriteria dengan tiap level, seperti pada tabel berikut:

\begin{tabular}{|c|c|c|c|}
\hline \multirow{2}{*}{ No } & \multirow{2}{*}{ Nama kriteria } & \multicolumn{2}{|c|}{ Persentase tiap level (\%) } \\
\hline & & Manager/ Supervisor & Staf \\
\hline 1 & Kedisplinan & 30 & 30 \\
\hline 2 & Pekerjaan & 30 & 40 \\
\hline 3 & Kemampuan Pribadi & 40 & 30 \\
\hline & Total & 100 & 100 \\
\hline
\end{tabular}

2. Bobot Jenis Penilai, untuk mengetahui bobot penilaian pada level pimpinan dengan level staff pada variabel penilaian, dapat dilihat pada tabel berikut:

\begin{tabular}{ccc}
\hline No & Jenis Penilai & Persentase (\%) \\
\hline 1 & Pimpinan atau atasan & 60 \\
2 & Bawahan atau rekan kerja & 40 \\
\hline
\end{tabular}

3. Bobot Jenis Penilai, yaitu bobot yang digunakan untuk menilai persentase variabel dan sub variabel, dapat dilihat pada tabel berikut: 


\begin{tabular}{|c|c|c|c|c|}
\hline No & Kriteria & No & Sub Kriteria & Bobot $(\%)$ \\
\hline \multirow{3}{*}{1} & \multirow{3}{*}{ Kedisplinan } & 1 & Kehadiran Pegawai & 10 \\
\hline & & 2 & Ketepatan waktu & 10 \\
\hline & & 3 & Sanksi & 10 \\
\hline \multirow{3}{*}{2} & \multirow{3}{*}{ Pekerjaan } & 1 & $\begin{array}{l}\text { Tidak adanya kesalahan dalam } \\
\text { menyelesaikan pekerjaan }\end{array}$ & 10 \\
\hline & & 2 & $\begin{array}{l}\text { Kemampuan menyelesaikan tugas } \\
\text { sesuai target dan tepat waktu }\end{array}$ & $20 / 10$ \\
\hline & & 3 & Pekerjaan sesuai SOP & 10 \\
\hline 3 & $\begin{array}{l}\text { Kemampuan } \\
\text { Pribadi }\end{array}$ & 1 & Kemapuan menyelesaikan masalah & 10 \\
\hline
\end{tabular}

Dari perhitungan pengolahan data penilaian kinerja tersebut diperoleh hasil persentase, sebagai berikut:

\section{Variabel Kedisiplinan}

Variabel Kedisiplinan terdiri dari beberapa sub variabel, antara lain: kehadiran pegawai, ketetapan waktu, dan sanksi. Berikut persentase sub variabel dari kedisiplinan dapat dilihat pada gambar di bawah ini:

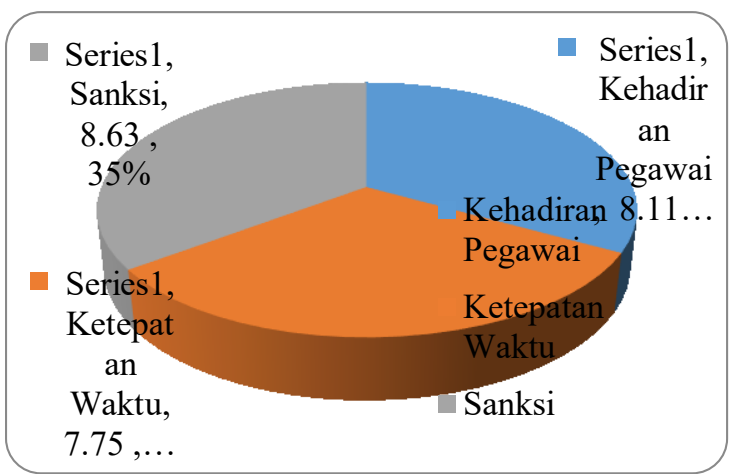

Gambar 1. Persentase Sub Variabel Kedisiplinan

Menjelaskan mengenai besaran persentase variabel kedisiplinan yaitu sub variabel kehadiran pegawai sebesar 33\%, sub variabel ketepatan waktu sebesar 32\%, dan sub variabel terhadap sanksi sebesar 35\%.

\section{Variabel Pekerjaan}

Variabel ini terdiri dari sub variabel yaitu antara lain: tidak adanya kesalahan dalam menyelesaikan pekerjaan, kemampuan menyelesaikan tugas sesuai target dan tepat waktu, 
dan pekerjaan sesuai SOP. Hasil persentase sub variabel pekerjaan, dapat dilihat pada gambar di bawah ini:

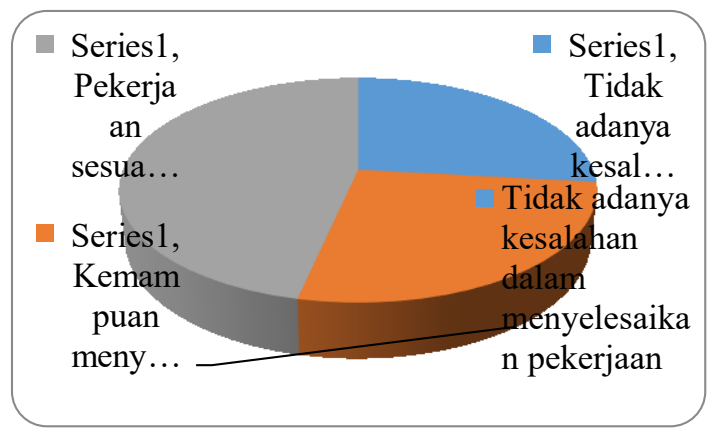

Gambar 2 Persentase Sub Variabel Pekerjaan

Menjelaskan mengenai pekerjaan dapat disimpulkan bahwa sub variabel tidak adanya kesalahan dalam menyelesaikan pekerjaan sebesar 27\%, sub variabel kemampuan menyelesaikan tugas sesuai target dan tepat waktu sebesar $27 \%$, dan sub variabel pekerjaan sesuai SOP sebesar $46 \%$.

a. Variabel Kemampuan Pribadi, variabel ini terdiri dari sub variabel antara lain kemampuan menyelesaikan masalah, kemampuan beradaptasi dengan kelompok kerja, dan kemampuan memimpin dalam kelompok. Hasil persentase sub variabel kemampuan pribadi dapat dilihat pada gambar di bawah ini:

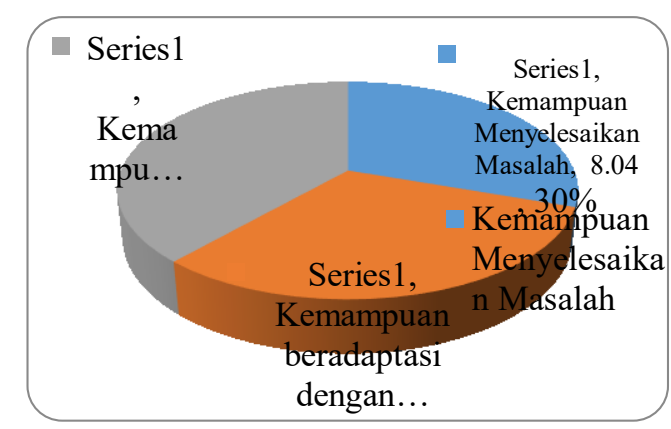

Gambar 3 Persentase Sub Variabel Kemampuan Pribadi

Menjelaskan mengenai kemampuan pribadi dapat disimpulkan bahwa sub variabel kemampuan menyelesaikan masalah sebesar 30\%, kemampuan beradaptasi dengan kelompok kerja sebesar 31\%, dan kemampuan memimpin dalam tim sebesar 39\%.

Dari penjelasan perhitungan penilaian kinerja pada masing-masing sub variabel di atas dapat ditarik kesimpulan secara global persentase variabel penilaian kinerja menggunakan metode 360 derajat sebagai berikut: 


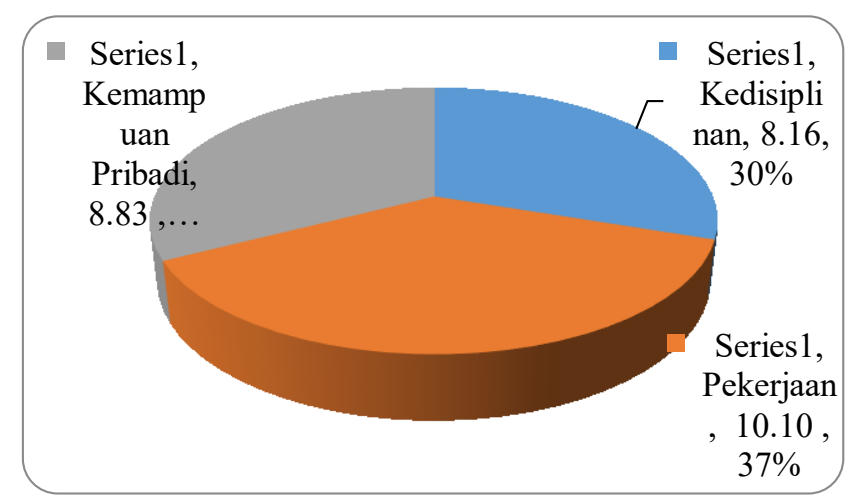

Gambar 4 Persentase Variabel Penilaian Kinerja secara keseluruhan

Dari gambar 4.6. di atas diperoleh hasil kesimpulan bahwa variabel yang digunakan dalam penilaian kinerja karyawan metode 360 derajat di PT Arga Bangun Bangsa, variabel Pekerjaan memperoleh bobot penilaian tertinggi sebesar 37\%, sedangkan variabel Kedisiplinan memperoleh bobot penilaian terendah sebesar 30\%, dilihat dari gambar persentase variabel tersebut dapat menjadi acuan atau dasar bahwa kedisiplinan harus menjadi perhatian khusus untuk diperhatikan dalam hal peningkatan kualitas kinerja karyawan. Apabila seluruh karyawan tidak memperhatikan kedisiplinan maka pencapaian target pribadi maupun perusahan tidak akan dapat diperoleh secara optimal dan tepat waktu. Apabila ini terjadi maka sulit bagi perusahaan untuk mencapai tujuan sesuai dengan misi visi yang telah dibentuk bersama sesuai target yang telah ditetapkan sebelumnya.

Dari variabel kemampuan pribadi memperoleh persentase tertinggi kedua setelah variabel kedisiplinan, variabel ini membantu manajemen untuk mengetahui kinerja karyawannya dalam menyelesaikan pekerjaan yang diamanahkan kepada mereka, apakah hasil dari pekerjaan tersebut sudah sesuai dengan yang diperintahkan dan untuk mengetahui apakah waktu penyelesaian pekerjaan tersebut telah sesuai dengan target ditetapkan. Dari variabel pekerjaan, setelah kami lakukan wawancara dengan beberapa pihak terkait umumnya karyawan di PT. Arga Bangun Bangsa, memiliki ketertarikan dan kenyamanan dalam pekerjaan yang mereka lakukan. Sehingga rasa suka terhadap pekerjaan tercermin dari analisa penilaian kinerja pada variabel pekerjaan yang memperoleh hasil persentase tertinggi dibandingkan dengan variabel yang lainnya.

Variabel-variabel yang digunakan dalam penilaian kinerja metode 360 derajat di PT. Arga Bangun Bangsa sangat membantu manajemen untuk melihat dan menganalisa hal-hal apa saja yang masih menjadi hambatan dan kekurangan bagi perusahaan dalam mencapai tujuan dan hal-hal apa saja yang harus dipertahankan dan ditingkatkan demi kemajuan perusahaan. 


\section{Analisis Optimalisasi Kinerja Dengan Menggunakan Metode 360 Derajat}

Dalam pengolahan perhitungan persentase penilaian kinerja karyawan menggunakan metode 360 derajat di PT. Arga Bangun Bangsa, akan dijabarkan secara detail variabel dan sub variabel yang digunakan untuk memberikan gambaran dan padangan mengenai besaran persentase yang diukur pada setiap direktorat. Hasil persentase ini dapat menjadi alat ukur dalam upaya seberapa optimalisasi penilaian kinerja dengan menggunakan metode 360 derajat di PT. Arga Bangun Bangsa. Persentase pengolahan variabel penilaian kinerja yang dilakukan pada setiap Direktorat di PT. Arga Bangun Bangsa adalah sebagai berikut:

Dari hasil presentase variabel-variabel yang digunakan pada penilaian kinerja metode 360 derajat di setiap direktorat yang ada di PT. Arga Bangun Bangsa menggambarkan bahwa penilaian kinerja metode 360 derajat memberikan optimalisasi yang cukup baik untuk menentukan direktorat terbaik dan direktorat yang harus lebih ditingkatkan performance karyawan di dalamnya. Seperti pada tabel di bawah ini:

Tabel 1. Perhitungan Penilaian Kinerja PT. Arga Bangun Bangsa dari Direktorat Peringkat Tertinggi Hingga Peringkat Terendah

\begin{tabular}{llcccc}
\hline No & \multicolumn{1}{c}{ Directorate } & \multicolumn{3}{c}{$\begin{array}{c}\text { Variabel Penilaian } \\
\text { (Dalam Persen \%) }\end{array}$} & $\begin{array}{c}\text { Total } \\
\text { Keseluruhan } \\
\text { Variabel per } \\
\text { Direktorat } \\
\text { (Dalam } \\
\text { Persen \%) }\end{array}$ \\
\hline 1 & IT \& Operational & 26.58 & 29.67 & 28.67 & 84.92 \\
2 & Human Capital & 24.44 & 30.00 & 29.44 & 83.88 \\
3 & Sales Directorate & 25.23 & 32.68 & 25.45 & 83.36 \\
4 & Training Directorate & 25.15 & 32.51 & 24.34 & 82.00 \\
5 & Finance \& Accounting & 23.72 & 29.55 & 27.83 & 81.10 \\
6 & Corporate Secretary & 25.15 & 28.27 & 25.55 & 78.97 \\
7 & Multimedia Creative & 21.21 & 29.50 & 24.21 & 74.92 \\
\hline & Dari tabel perhitungan data penilaian kinerja karyawan PT. Arga Bangun Bangsa dapat \\
\hline
\end{tabular}

diperoleh data direktorat terbaik berdasarkan pada variabel yang digunakan pada penilaian kinerja metode 360 derajat, secara keseluruhan nilai tertinggi terdapat pada karyawan di direktorat IT dan Operational dengan nilai sebesar 28.31 sedangkan nilai terendah terdapat pada karyawan di direktorat Multimedia Creative dengan nilai sebesar 24.97. Dari hasil penilaian tersebut menandakan bahwa karyawan di direktorat IT dan Operational sudah memiliki kinerja yang baik dan hasil pekerjaan yang baik pula, adanya reward yang diberikan pada karyawan programmer yang terdapat di direktorat IT dan Operational menjadi salah satu bukti bahwa 
manajemen sangat konsen dan fokus dalam peningkatan kinerja karyawan yaitu dengan memberikan penghargaan kepada karyawan yang berprestasi sebagai ucapan terima kasih atas kontribusinya terhadap kemajuan perusahaan.

Pada umumnya setiap karyawan membutuhkan perhatian dan bimbingan dari atasannya, agar mereka bisa memberikan kualitas pekerjaan yang baik. Pelaksanaan penilaian kinerja metode 360 derajat memberikan hasil optimalisasi penilaian yang tergambar pada tabel perhitungan penilaian kinerja sebagai berikut:

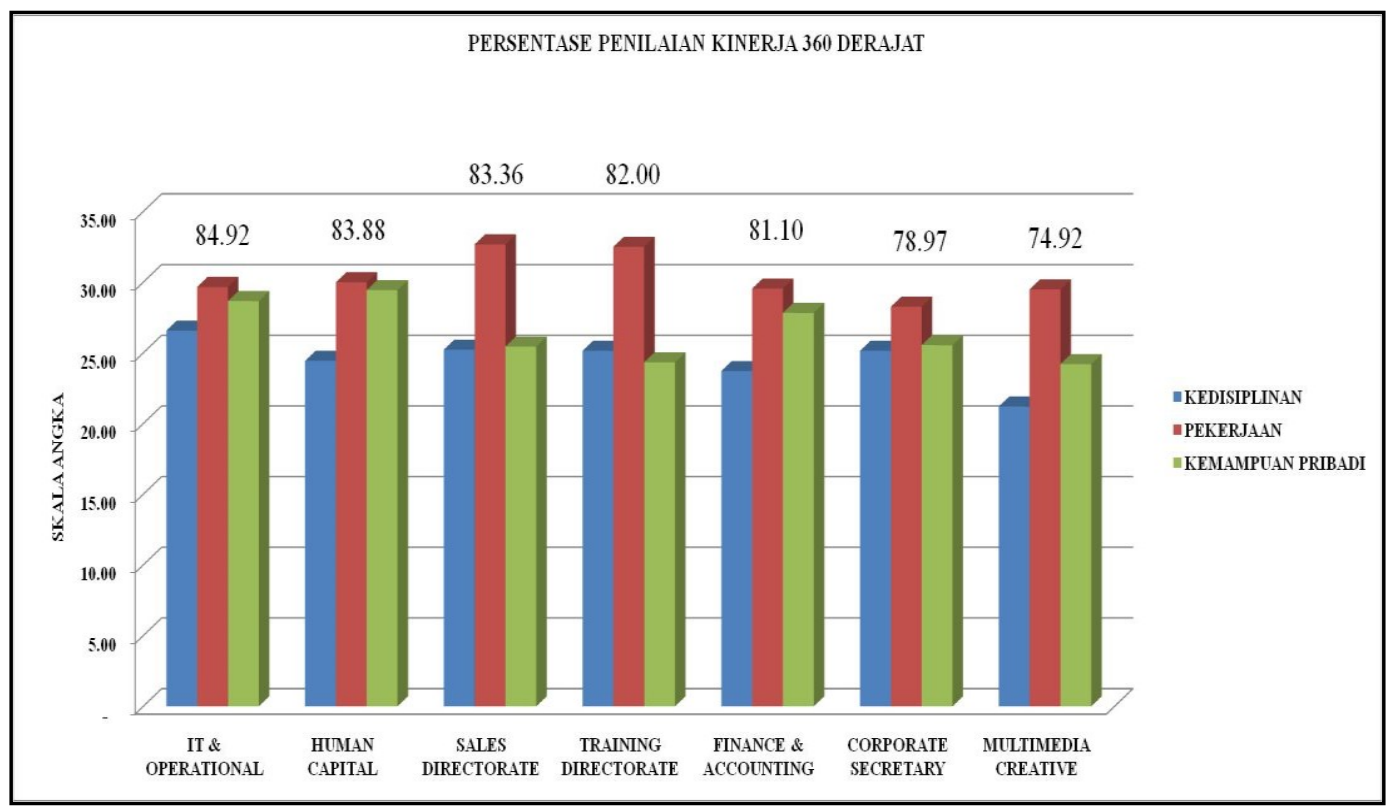

Dari hasil implementasi pelaksanaan dan penggunaan penilaian kinerja dengan metode 360 derajat di PT Arga Bangun Bangsa dapat memberikan informasi mengenai optimalisasi penilaian kinerja metode 360 derajar tersebut, sehingga terangkum manfaat, arah, dan tujuan yang diperoleh sebagai berikut:

1. Pengembangan Individu

a. Memperbaiki persepsi individu tentang seseorang dengan mencoba memahami bagaimana seseorang melihat orang lain

b. Membantu individu untuk mengatur unjuk kerjanya menjadi lebih baik

c. Memfasilitasi proses pembelajaran bagi karyawan

2. Pengembangan Tim Kerja

a. Meningkatkan komunikasi interpersonal diantara anggota tim kerja

b. Meningkatkan kerja sama antara direktorat yang satu dengan yang lainnya 
3. Pengembangan Sumber Daya Manusia atau Audit Manajemen Sumber Daya Manusia, konsep ini dapat digunakan dalam hal:

a. Proses rekrutmen dan seleksi

b. Pelatihan karyawan

c. Pengambilan keputusan personalia secara umum seperti promosi, kenaikan upah, status percobaan ataupun terminasi karyawan

d. Bidang pelatihan dan juga pengembangan karyawan, termasuk pengembangan manajemen atau organisasi

e. Perencanaan untuk mengukur atau mengelola pusat pengembangan seperti potensi kepemimpinan, perkembangan, peningkatan kompetensi, perencanaan karir, dan perkembangan karir karyawan.

Berdasarkan hasil penilaian tersebut apresiasi berupa penghargaan diberikan bagi karyawan yang berprestasi, sedangkan bagi karyawan dengan penilaian kinerja terendah diberikan pengarahan untuk dapat memperbaiki kekurangannya agar kedepannya bisa menjadi lebih baik. Dari hasil implementasi pelaksanaan dan penggunaan penilaian kinerja dengan metode 360 derajat di PT Arga Bangun Bangsa dapat memberikan informasi mengenai optimalisasi penilaian kinerja metode 360 derajar tersebut, sehingga terangkum manfaat, arah, dan tujuan yang diperoleh sebagai berikut:

1. Pengembangan Individu

a. Memperbaiki persepsi individu tentang seseorang dengan mencoba memahami bagaimana seseorang melihat orang lain

b. Membantu individu untuk mengatur unjuk kerjanya menjadi lebih baik

c. Memfasilitasi proses pembelajaran bagi karyawan

2. Pengembangan Tim Kerja

a. Meningkatkan komunikasi interpersonal diantara anggota tim kerja

b. Meningkatkan kerja sama antara direktorat yang satu dengan yang lainnya

3. Pengembangan Sumber Daya Manusia atau Audit Manajemen Sumber Daya Manusia, konsep ini dapat digunakan dalam hal:

a. Proses rekrutmen dan seleksi

b. Pelatihan karyawan 
c. Pengambilan keputusan personalia secara umum seperti promosi, kenaikan upah, status percobaan ataupun terminasi karyawan

d. Bidang pelatihan dan juga pengembangan karyawan, termasuk pengembangan manajemen atau organisasi

e. Perencanaan untuk mengukur atau mengelola pusat pengembangan seperti potensi kepemimpinan, perkembangan, peningkatan kompetensi, perencanaan karir, dan perkembangan karir karyawan.

\section{PENUTUP}

\section{Kesimpulan}

Metode penilaian kinerja 360 derajat didefinisikan sebagai metode penilaian kinerja yang dilakukan oleh banyak pihak untuk memperoleh hasil yang lebih jujur, adil, dan tepat sasaran. Proses penilaian kinerja yang dilakukan di PT. Arga Bangun Bangsa terdiri dari input, meliputi praktik-praktik atau aktivitas yang biasa dilakukan sebelum penilai melakukan tugasnya dan orang yang dinilai melakukan umpan balik. Process, Pekerjaan penilai sebenarnya dimulai ketika mereka yang dinilai menerima hasil penilaian. Outcomes, merupakan laporan yang diperoleh dari proses penilaian 360 derajat.

Dalam teknis pelaksanaannya perlu adanya pemberian bobot penilaian kepada masing-masing penilai. Penilaian kinerja metode 360 derajat di PT. Arga Bangun Bangsa menggunakan 3 (tiga) variabel sebagai berikut:

1. Variabel Kedisiplinan, terdiri dari sub variabel yaitu: Kehadiran Pegawai, Ketepatan Waktu, dan Sanksi.

2. Variabel Pekerjaan, terdiri dari sub variabel yaitu: Tidak adanya kesalahan dalam menyelesaikan pekerjaan, Kemampuan menyelesaikan tugas sesuai target dan tepat waktu, dan Pekerjaan sesuai SOP

3. Variabel Kemampuan Pribadi, terdiri dari sub variabel yaitu: Kemampuan menyelesaikan masalah, Kemampuan beradaptasi dengan kelompok kerja, dan Kemampuan memimpin dalam tim.

4. Optimalisasi penilaian kinerja karyawan dapat terukur dengan adanya perhitungan persentase variabel dan bobot penilaian yang digunakan. Dimana hasil perhitungannya dari nilai tertinggi hingga terendah, sebagai berikut: 
a. IT dan Operational Directorate, nilai rata-rata sebesar $84.92 \%$

b. Human Capital Directorate, nilai rata-rata sebesar $83.88 \%$

c. Sales Directorate, nilai rata-rata sebesar $83.36 \%$

d. Training Directorate, nilai rata-rata sebesar $82.00 \%$

e. Finance dan Accounting Directorate, nilai rata-rata sebesar $81.10 \%$

f. Corporate Secretary, nilai rata-rata sebesar $78.97 \%$

g. Multimedia Creative Directorate, nilai rata-rata sebesar $74.92 \%$

Berdasarkan hasil penilaian tersebut apresiasi berupa penghargaan diberikan bagi karyawan yang berprestasi, sedangkan bagi karyawan dengan penilaian kinerja terendah diberikan pengarahan untuk dapat memperbaiki kekurangannya agar kedepannya bisa menjadi lebih baik. Dari hasil kesimpulan-kesimpulan yang telah dikemukakan di atas, maka dapat diajukan beberapa rekomendasi sebagai masukan bagi pihak manajemen PT. Arga Bangun Bangsa sebagai berikut:

1. Dalam meningkatan efektivitas penilaian kinerja, manajemen harus melibatkan karyawan yang dinilai untuk ikut serta memberikan penilaian kepada dirinya sendiri, karena penilaian 360 derajat yang dilakukan hanya melibatkan pimpinan, rekan kerja, dan bawahan. Hal ini bertujuan agar karyawan yang dinilai tidak merasa bahwa penilaiannya besifar subjektif dan agar karyawan dapat mengukur kinerjanya sendiri.

2. Rentan waktu yang begitu pendek dalam pelaksanaan penilaian kinerja metode 360 derajat membuat banyak para penilai yang mengumpulkan form penilaian yang telah dilengkapi melebihi batas waktu pengumpulan, akibatnya banyak penilai yang mengisinya secara terburu-buru agar segera dapat dikumpulkan, padahal hal tersebut dapat menimbulkan pemberian nilai secara asal-asalan atau tidak memperhatikan secara detail antara variabel yang dinilai dengan kualitas pekerjaan karyawan yang dinilai.

3. Dalam pelaksanaan penilaian kinerja dengan metode 360 derajat ini memerlukan effort yang cukup besar, karena melibatkan penilai yang lebih dari satu orang untuk menilai karyawan. Sebaiknya PT. Arga Bangun Bangsa bisa merancang suatu aplikasi penilaian (software) untuk memudahkan penilai dalam memberikan penilaian serta memberikan kemudahan dalam melakukan kompilasi dan membuat laporan kinerja karyawan keseluruhan. 


\section{DAFTAR PUSTAKA}

Amir, M. Taufiq. 2011. Manajemen Strategik. Jakarta: PT RajaGrafindo Persada.

Arif, Iman Setiadi. 2016. Psikologi Positif. Jakarta: PT Gramedia Pustaka Utama.

Astuti, Dyah Ayu Lestari Windi. 2006. Penciptaan Sistem Penilaian Kinerja Yang Efektif Dengan Assessment Centre. Jurnal Manajemen. Vol. 1. No. 1.

Assauri, Sofjan. 2013. Strategic Management. Jakarta: PT RajaGrafindo Persada.

Fachrizal, Eka dan Ginting, Abadi. 2013. Penilaian Kinerja Karyawan Dengan Menggunakan Metode 360 Degree Feedback Pada Hotel XYZ Medan. Medan: e-Jurnal Teknik Industri FT USU. Vol 3, No. 1:7-14.

Hanggraeni, Dewi. 2012. Manajemen Sumber Daya Manusia. Jakarta: Lembaga Penerbit Fakultas Ekonomi Universitas Indonesia.

Https://michaeladryanto.wordpress.com. Mengenali Metode Penilaian 360 Derajat. 2011.

Https://ronawajah.wordpress.com. Penilaian kinerja karyawan umpan balik 360 derajat. 2009

Ndara, Taliziduhu. 2012. Pengantar Teori Pengembangan Sumber Daya Manusia. Jakarta: Rineka Cipta

Pace, R. Wayne dan Don F. Faules. 2001. Komunikasi Organisasi. Bandung: PT Remaja Rosdakarya.

Pardosi, Jhonli, Tambunan, Mangara M., dan Syahputri, Khalida. 2013. Pengukuran Kinerja Dengan Menggunakan Integrasi 360 Derajat Feedback dan AHPdi PT. S. Medan: eJurnal Teknik Industri FT USU. Vol 3, No. 2:1-7.

Rachmayati, Fachrully. 2006. Performance Appraisal 360 Derajat Feedback: Sebuah Pendekatan Untuk Menciptakan Competitive Advantage Bagi Organisasi”. Vol 5 No 2.

Ratnaningsih, Ika Zenita. 2011. Metode Umpan Balik 360 Derajat Untuk Mengembangkan Kepemimpinan Dalam Talent Management System. Dimuat dalam proceeding, ISBN : 978-979-097-184-4.

Rivai, Veithzal. 2004. Manajemen Sumber Daya Manusia Untuk Perusahaan Dari Teori Ke Praktek. Jakarta: PT RajaGrafindo Persada.

Rivai, Veithzal, Basri, Ahmad Fawzi Mohd., Sagala, Ella Jauvani, dan Murni, Silviana. 2005. Performance Apraisal. Jakarta: PT RajaGrafindo Persada.

Rivai, Veithzal. 2005. Performance Appraisal: Sistem yang Tepat untuk Menilai Kinerja Perusahaan dan Meningkatkan Daya Saing Perusahaan. Jakarta: PT. Raja Grafindo Persada Jakarta.

Sulistyani, Ambar Teguh dan Rosidah, 2009, Manajemen Sumber Daya Manusia: Konsep, Teori, dan Pengembangan Dalam Konteks Organisasi Publik. Jakarta: Graha Ilmu.

Widya, Rita. 2004. Penilaian Kinerja Dengan Menggunakan Konsep 360 Derajat Feedback. Yogyakarta: Jurnal Ekonomi dan Kewirausahaan. Vol. 4, No. 1:86-95.

Widyowati, Arini. 2010. Penilaian Kinerja 360 Derajat Sebagai Usaha Meningkatkan Persepsi Positif Terhadap Keadilan Prosedural Penilaian Kinerja. Yogyakarta: Jurnal Humanitas. Vol. VII. No. 1. 